Brit. J. vener. Dis. (1965), 41, 170.

\title{
PROBLEM OF POSITIVE COMPLEMENT-FIXATION REACTIONS WITH THE REITER TREPONEME IN THE ABSENCE OF SYPHILIS ROLE OF A POLYSACCHARIDE ANTIGEN*
}

\author{
BY \\ J. PILLOT, A. BETZ, J. COLOMBANI, AND J. RIPAULT \\ From the Laboratory of Antigen Biochemistry, Pasteur Institute, Paris, the State Laboratory of the Grand Duchy of \\ Luxemburg, and the Central Serology Laboratory of the Assistance Publique de Paris (Hôpital St. Louis) \\ WITH THE TECHNICAL ASSISTANCE OF \\ S. D'AZAMBUJA
}

In the sero-diagnosis of the treponematoses, the complement-fixation reaction with the Reiter treponeme reveals the group anti-protein, an antibody to an antigen of protein nature common to $T$. pallidum and the Reiter treponeme (d'Alessandro and Dardanoni, 1953; Pillot and Faure, 1959; Pillot, Dupouey, and Faure, 1960). The polysaccharides (Pillot and Dupouey, 1964) of the Reiter treponeme fix complement only in the presence of anti-Reiter sera; these polysaccharide antigens and lipid hapten (Faure and Pillot, 1960), in Reiter treponeme, do not combine with the antibodies specific for the treponematoses.

Immunological analysis of the Reiter treponeme has shown that it is closely related to the Kazan treponeme and $T$. phagedenis, and also related to $T$. refringens, $T$. calligyra, and $T$. minutum (Dupouey, $1962 ; 1963)$. The four last-named treponemes were isolated from human genital mucosa. The existence of antigens common to the Reiter treponeme and $T$. zuelzerae is alsso known, the latter organism being found in mud (de Bruijn, 1961). In other words, antigenic relationships seem to be, if not constant, at least frequent among treponemes.

Moreover, all the human and animal sera we have studied (Pillot, 1962) contain antibodies agglutinating the Reiter treponeme; these antibodies do not fix complement and hence do not interfere with the group anti-protein in the sero-diagnosis of treponematosis. Such antibodies, called "natural", are very probably elicited by numerous more or less saprophytic treponemes found in all human beings. We know that the antibodies in question are mostly antipolysaccharide antibodies (Pillot and Dupouey,

* Received for publication January 22, 1965.
1964), and we are tempted to believe that these are group antibodies corresponding to polysaccharide antigens common to numerous treponemes.

With these facts in mind, it was considered to be of interest to study further the specificity of complement-fixation reactions obtained with the Reiter treponeme. The present study demonstrates the existence of positive complement-fixation reactions with the sera of certain human subjects exempt from treponematoses, these reactions being linked to a polysaccharide-antipolysaccharide system.

\section{Materials and Methods}

The Reiter treponemal antigen (Serpasteur) used in the sero-diagnosis of syphilis is an ultrasonate of the Reiter treponeme in a pH 8 buffer with an equal volume of glycerin (Pillot and Faure, 1959). This preparation, compared with others, presents the advantages of specificity, sensitivity, and stability (Szernovicz and d'Azambuja, 1960). At its optimum concentration, it contains roughly $0.1 \mathrm{mg}$. dry substances per $\mathrm{ml}$.

The sera used came from the State Laboratory of the Grand Duchy of Luxemburg or from the Central Serology Laboratory of the Assistance Publique de Paris (Hôpital Saint Louis).

In Luxemburg, sera from patients under treatment for any kind of disease and sera from voluntary blood donors unlikely to have treponematosis are classified separately. In Paris, all the sera examined came from patients.

Three serological reactions are systematically practised in routine serology in these laboratories: the Kline and Kolmer reactions with cardiolipin antigens, and the Kolmer technique with the Reiter treponemal antigen. In Luxemburg, the complement-fixation reactions are performed on trays, in Paris in tubes. 
The percentage of sera negative with cardiolipin antigen (both the Kline and the Kolmer reactions being negative) and positive with the Reiter treponemal antigen are reported in Table I. The number is distinctly higher in Luxemburg ( $2 \cdot 75$ and 1.5 per cent.) than in Paris $(0.43$ per cent. $)$

A certain number of sera negative with the cardiolipin antigen and positive with the Reiter treponemal antigen (Table I) were submitted to the treponemal immobilization test (classic method without lysozyme); a possible syphilitic history not mentioned in the request for serological examination was sought out. The results are given in Table II. The highest frequency of positive treponemal immobilization (TPI) tests is correlated with the highest incidence of syphilis among the subjects examined, patients being compared to blood donors. The sera yielding negative TPI tests for which no history of syphilis was found are labelled "isolated Reiter positive".

TABLE I

FREQUENCY OF POSITIVITY WITH THE REITER TREPONEME (R) AMONG SERA NEGATIVE WITH CARDIOLIPIN ANTIGEN (CL)

\begin{tabular}{|c|c|c|c|c|}
\hline \multirow{2}{*}{ Clinic } & \multirow{2}{*}{. $\quad \cdots$} & \multicolumn{2}{|c|}{ Luxemburg } & \multirow{2}{*}{ Paris } \\
\hline & & Patients & $\begin{array}{l}\text { Blood } \\
\text { Donors }\end{array}$ & \\
\hline \multicolumn{2}{|c|}{ Number of Sera Examined } & 12,000 & 11,500 & 146,500 \\
\hline Sera $C L \cdot, \mathbf{R}-$ & $\begin{array}{l}\text { No. } \\
\text { Per cent. }\end{array}$ & $\begin{array}{l}330 \\
2 \cdot 75\end{array}$ & 174 & $\begin{array}{r}635 \\
0.43\end{array}$ \\
\hline \multicolumn{2}{|c|}{$\begin{array}{c}\text { Number of Sera Examined by } \\
\text { TPI } \ldots \\
\text {. }\end{array}$} & 80 & 53 & 104 \\
\hline
\end{tabular}

TABLE II

PERCENTAGE TREPONEMAL IMMOBILIZATION (TPI) TESTS MADE ON SERA NEGATIVE WITH CARDIOLIPIN ANTIGEN AND POSITIVE WITH REITER TREPONEMAL ANTIGEN (R)

\begin{tabular}{|c|c|c|c|}
\hline \multirow{2}{*}{ TPI Tests } & \multicolumn{2}{|c|}{ Luxemburg* } & \multirow{2}{*}{ Paris } \\
\hline & Patients & $\begin{array}{c}\text { Blood } \\
\text { Donors }\end{array}$ & \\
\hline 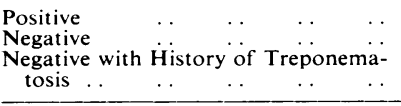 & $\begin{array}{r}45 \\
55 \\
3 \cdot 7 \\
\end{array}$ & $\begin{array}{r}5 \cdot 6 \\
94 \cdot 4 \\
0 \\
\end{array}$ & $\begin{array}{l}40 \cdot 5 \\
59 \cdot 5 \\
21 \\
\end{array}$ \\
\hline $\begin{array}{l}\mathbf{R} \text { as Basis of Reaction Specific for } \\
\text { Treponematosis }\end{array}$ & $48 \cdot 7$ & $5 \cdot 6$ & $61 \cdot 5$ \\
\hline $\begin{array}{l}\mathbf{R} \text { as Basis of Reaction Non-specific } \\
\text { for Treponematosis. }\end{array}$ & $51 \cdot 3$ & $94 \cdot 4$ & $38 \cdot 5$ \\
\hline
\end{tabular}

* We thank Dr Becker, Rijks Institut Voor de Volksgezondheid, Utrecht, who carried out the immobilization tests on sera from Luxemburg.

Of these sera with "isolated Reiter positive" reaction, 77 were submitted in the Pasteur Institute laboratory to other immunological tests designed to detect the precise nature of the antibody involved in the complement fixation reaction with the Reiter treponeme. The following tests were made on undiluted sera and on the first three dilutions of each serum $(1 / 2,1 / 4,1 / 8)$ :
(1) A Kline and a Kolmer reaction with cardiolipin antigen. These reactions were in all cases negative, as they had been in the first laboratory.

(2) A Kolmer technique with the Reiter treponemal antigen, including dilutions of this antigen above and below the optimal dilution.

(3) A Kolmer technique with a polysaccharide preparation of the Reiter treponeme obtained as in Pillot and Dupouey (1964); the treponemes, after ultrasonic treatment at $\mathrm{pH} 11 \cdot 5$, were submitted to papaïn digestion, and then heated to $120^{\circ} \mathrm{C}$.; the polysaccharide fraction soluble in 20 per cent. trichloracetic acid was used without purification by organic solvents. This preparation is called non-purified polysaccharide extract $(\mathrm{np})$; it is used at the optimal antigen concentration as regards antiReiter sera, at a concentration twice as strong, and at a concentration half as strong as the optimum.

(4) A Kolmer technique with an ultrasonically-treated suspension of $T$. minutum. Dupouey (1962) showed that this treponeme has the group protein in common with the Reiter treponeme, but that their polysaccharide antigens are different. This preparation, at its antigenic optimum as regards syphilitic sera, fixes complement with sera from a certain number of healthy individuals which do not fix complement with the Reiter treponemal antigen. A negative reaction with this antigen confirms the absence of group antiprotein antibody, but a positive reaction does not necessarily reveal it.

(5) A Kolmer technique with an ultrasonically-treated suspension of $T$. pallidum (Vaisman and Hamelin, 1961)*. As shown in Table III, such a preparation is particularly active as regards syphilitic sera because of the group protein it contains, this group protein constituting the dominant immunological system. The ultrasonically treated $T$. pallidum suspension fixes complement in the presence of some sera from normal subjects. As for $T$. minutum, this preparation is useful only to confirm the absence from the sera of group protein antibody.

\section{TABLE III}

COMPLEMENT-FIXATION ACTIVITY OF AN ULTRASONICALLY-TREATED SUSPENSION OF T. Pallidum, OF A REITER TREPONEMAL ANTIGEN, AND OF A CARDIOLIPIN ANTIGEN, WITH A HUMAN SYPHILITIC SERUM BEFORE AND AFTER EXHAUSTION BY THE REITER TREPONEME AND CARDIOLIPIN, AND OF A RABBIT ANTI-REITER SERUM

\begin{tabular}{|c|c|c|c|}
\hline Serum & T. pallidum & $\begin{array}{l}\text { Reiter } \\
\text { Treponemal } \\
\text { Antigen }\end{array}$ & Cardiolipin \\
\hline $\begin{array}{c}\text { Syphilitic Serum } \\
\text { Exhausted by }\end{array}$ & $\begin{array}{l}+++ \\
+ \\
-\end{array}$ & $\begin{array}{l}+++ \\
- \\
-\end{array}$ & $\begin{array}{l}++++ \\
+++ \\
-\end{array}$ \\
\hline $\begin{array}{l}\text { Anti-Reiter Serum } \\
\text { Exhausted by Reiter } \\
\text { Treponeme } \ldots\end{array}$ & $+t+$ & $\begin{array}{l}+++ \\
-\end{array}$ & - \\
\hline
\end{tabular}

* We thank Dr A. Vaisman of the Institut Fournier, Paris, for his gift of this preparation. 
(6) A Reiter treponemal agglutination reaction according to ${ }^{*}$ Roemer and Schlipköter (1958). We confirmed, with these authors' suspension, that this reaction reveals the group antiprotein antibody by thermal denaturation of natural antibodies. We however found the reaction weak in sensitivity.

(7) An indirect immunofluorescence reaction, with $T$. pallidum, and with the Reiter treponeme. As has already been shown (Pillot and Borel, 1961) the group antiprotein is the origin of the cross-reaction between the sera of syphilitic subjects and the Reiter treponeme. The conjugated human fluorescent antiglobulins used agglutinates $\mathrm{ORH}+$ red cells sensitized by an anti-D human serum, to a dilution of $1 / 32,000$; it is tagged by six molecules of fluorescein per molecule of antibody; its optimal dilution for use in immunofluorescence is 1/300 (Pillot and Daguet, 1964). In this study, we considered positive reactions with a serum dilution of $1 / 50$ or higher for the Reiter treponeme and of $1 / 150$ or higher for $T$. pallidum to be significant.

Three protein extracts of the Reiter treponeme were prepared: one was obtained according to d'Alessandro's original method (ATPS: d'Alessandro and Dardanoni, 1953), one according to the modification of de Bruijn (1960), and one according to the method described by Pillot and Faure (1959).

\section{Results}

\section{General Analysis of Results}

The 77 sera found to show an "isolated Reiter positive" reaction were classified into five categories (Table IV).

\footnotetext{
* We thank Dr G. B. Roemer for having sent us his suspension.
}

(1) Thirteen sera for which the positive reaction with the Reiter treponemal antigen was not demonstrated. As with normal sera, the reactions with ultrasonically-treated suspensions of $T$. minutum and $T$. pallidum were negative, positive, or dissociated.

(2) Eighteen anticomplementary sera. The anticomplementary character fades out with dilution of the serum, but a limit of dilution exists at which the reaction is still positive in the presence of the Reiter treponemal antigen and negative with the other antigens, especially the cardiolipin antigen.

(3) 22 sera fixing complement with the Reiter polysaccharide extract (np). The polysaccharide reaction presents a marked zone phenomenon with inhibition by excess of antigen and of antibody. These sera fix complement with the Reiter treponemal antigen because of the polysaccharides in this preparation; the antigenic optimum of the polysaccharide-antipolysaccharide system are then situated at a dilution three times higher than the antigenic optimum of the system group proteinantiprotein. As regards the suspension of $T$. minutum and of $T$. pallidum, all eventualities are possible. The agglutination and the immunofluorescence reactions ( $T$. pallidum, Reiter treponeme) are regularly negative.

(4) Nine sera presenting group antiprotein. These sera fix complement with the Reiter treponemal antigen; the antigenic optimum of the system is identical with that determined in regard to syphilitic serum, i.e.

\begin{tabular}{|c|c|c|c|c|c|c|c|c|c|c|c|c|c|}
\hline \multicolumn{14}{|c|}{ ONLY RESULTS OBTAINED胥T } \\
\hline \multirow{3}{*}{ Category } & \multirow{3}{*}{$\begin{array}{l}\text { Per cent. } \\
\text { of Cases }\end{array}$} & \multirow{3}{*}{$\underset{\text { Serum }}{\text { Dilution }}$} & & & & & \multicolumn{6}{|c|}{ Kolmer Technique } & $\widehat{\omega}$ \\
\hline & & & \multicolumn{4}{|c|}{ Reiter Treponemal Antigen } & \multicolumn{3}{|c|}{$\begin{array}{l}\text { Reiter Polysaccharide } \\
\text { Extract (np)* }\end{array}$} & \multirow{2}{*}{$T \cdot \underset{\text { tum }}{\min u-}$} & \multirow{2}{*}{$\begin{array}{l}\text { T. palli- } \\
\text { dum }\end{array}$} & \multirow{2}{*}{$\begin{array}{c}\text { Cardio- } \\
\text { lipin }\end{array}$} & \multirow{2}{*}{ 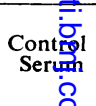 } \\
\hline & & & $1 / 26$ & $1 / 80$ & $1 / 240$ & $1 / 720$ & $1 / 360$ & $1 / 1,080$ & $1 / 3,240$ & & & & \\
\hline 1 & 17 & $1 / 1$ & - & - & - & - & - & - & - & $\begin{array}{l}++++ \\
\text { or }-\end{array}$ & $\begin{array}{l}++++ \\
\text { or }-\end{array}$ & - & \\
\hline 2 & 23 & $\begin{array}{l}1 / 1 \\
1 / 2 \\
1 / 4 \\
\end{array}$ & $\begin{array}{l}++++ \\
++++ \\
++\end{array}$ & $\begin{array}{l}++++ \\
++++ \\
++\end{array}$ & $\begin{array}{l}++++ \\
++++ \\
++\end{array}$ & $\begin{array}{l}+++ \\
++++ \\
\end{array}$ & $\begin{array}{l}++++ \\
++++ \\
+\end{array}$ & $\begin{array}{l}++++ \\
++++ \\
+\end{array}$ & $\begin{array}{l}++++ \\
++++\end{array}$ & $\begin{array}{l}++++ \\
++++\end{array}$ & $\begin{array}{l}++++ \\
+++ \\
\end{array}$ & $\begin{array}{l}++++ \\
++++\end{array}$ & $\begin{array}{l}++P_{+} \\
+\quad \text { D }\end{array}$ \\
\hline 3 & 29 & $\begin{array}{l}1 / 1 \\
1 / 2 \\
1 / 4 \\
1 / 8\end{array}$ & $\begin{array}{l}+++ \\
= \\
-\end{array}$ & $\begin{array}{l}++++ \\
++++ \\
-\end{array}$ & $\begin{array}{l}++++ \\
++++ \\
++++ \\
+ \\
\uparrow\end{array}$ & $\begin{array}{l}++ \\
\pm \\
- \\
-\end{array}$ & $\begin{array}{l}++++ \\
++++ \\
+\end{array}$ & $\begin{array}{l}++++ \\
++++ \\
++++ \\
++\end{array}$ & $\begin{array}{l}\overline{+} \\
+ \\
+ \\
+\end{array}$ & $\begin{array}{l}++++ \\
\text { or } \\
-\end{array}$ & $\begin{array}{l}++++ \\
\text { or }\end{array}$ & $\begin{array}{l}- \\
- \\
-\end{array}$ & $\begin{array}{l}=\bar{N} \\
=N \\
=N\end{array}$ \\
\hline 4 & 12 & $\begin{array}{l}1 / 1 \\
1 / 2 \\
1 / 4\end{array}$ & $\begin{array}{l}++++ \\
+++ \\
-\end{array}$ & $\begin{array}{l}++++ \\
++++ \\
++ \\
+\end{array}$ & $\begin{array}{l}++++ \\
+++ \\
-\end{array}$ & $\begin{array}{l}++++ \\
-\end{array}$ & $\begin{array}{l}\overline{-} \\
\overline{-}\end{array}$ & $\begin{array}{l}- \\
-\end{array}$ & $\begin{array}{l}\overline{-} \\
\overline{-}\end{array}$ & $\begin{array}{l}++++ \\
++++ \\
+\end{array}$ & $\begin{array}{l}++++ \\
++++ \\
+\end{array}$ & $\begin{array}{l}- \\
\overline{-}\end{array}$ & 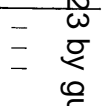 \\
\hline 5 & 19 & $\begin{array}{l}1 / 1 \\
1 / 2\end{array}$ & $\stackrel{+++}{+}$ & ++++ & $\begin{array}{l}++ \\
\pm\end{array}$ & \pm & $\overline{-}$ & $\overline{-}$ & $\overline{-}$ & $\begin{array}{l}++++ \\
\text { or }-\end{array}$ & $\underset{\text { or }-++}{+++}$ & - & $-\mathbb{E}$ \\
\hline
\end{tabular}
The antigenic optima are indicated by arrows; in the case of the polysaccharide extract (np), the optimal dilution as regards a rabbit anti-
Reiter serum $=1 / 1,080$. 
$1 / 80$. No fixation occurs with the polysaccharide extract. Roemer agglutination is positive in onethird of cases. Immunofluorescence is positive with $T$. pallidum (except in one case), and less frequently positive with the Reiter treponeme. For these nine sera, a clinical history was again suspected. In three cases, the existence of syphilis correctly treated and cured was discovered. One of these sera was that of a patient treated in 1945 for primary syphilis; his serum, "isolated Reiter positive" to a dilution of $1 / 8$, fixed complement with $T$. minutum and $T$. pallidum and showed Roemer agglutination to a dilution of $1 / 120$. In contrast, this serum was negative in immunofluorescence with $T$. pallidum.

(5) Fifteen sera impossible to classify in the other four categories did not fix complement with the Reiter treponemal antigen beyond the dilution of $1 / 2$ (except the sera showing anticomplementary activity at the start). The antigenic optimum here was that of the group protein-antiprotein system. All eventualities are possible as regards $T$. minutum and $T$. pallidum. The other reactions are negative.

\section{STUdy OF THE Polysaccharide-ANTIPOLY- SACCHARIDE SYSTEM FIXING COMPLEMENT}

We had the good fortune to discover a blood donor whose serum showed an antipolysaccharide antibody fixing complement, thus permitting us to undertake easily the immunological study of this system. The antipolysaccharide antibody in question could be demonstrated only by the complementfixation reaction. On the one hand, the sera containing this antibody do not agglutinate the Reiter treponeme or red cells sensitized with the polysaccharide extract (np) at a dilution above that of sera not containing it. On the other hand, we have never found by gel analysis a precipitation band attributable to this system. As already mentioned, tests by immunofluorescence are regularly negative.

Like the majority of polysaccharide antigens of the Reiter treponeme, after treatment with the polysaccharidase from the snail stomach, this polysaccharide loses its ability to fix complement (Pillot and Dupouey, 1964). Following the action of water saturated with butanol, lauryl sulphate, by optical and by electron microscopy, we note that this polysaccharide fraction is dispersed at the same time as the treponemal sheath and as the most exterior part of this sheath. The group protein, on the contrary, is revealed simultaneously with the progressive alteration of the sheath, but the group protein activity remains linked to the body of the treponeme (Pillot, Dupouey, and Ryter, 1964; Pillot, 1965). The polysaccharide in question is therefore strictly localized in the sheath of the organism.

We have studied, with the antipolysaccharide, three extracts called "of protein nature" obtained by the methods of d'Alessandro and Dardanoni (1953), de Bruijn (1960), and Pillot and Faure (1959). The results, compared with those obtained with rabbit anti-Reiter serum and syphilitic serum are

IV

WITH "ISOLATED REITER POSITIVE" REACTION. SIGNIFICANT DILUTIONS ARE SHOWN

\begin{tabular}{|c|c|c|c|c|c|}
\hline \multicolumn{2}{|c|}{ Roemer Agglutination } & \multicolumn{3}{|c|}{ Immunofluorescence } & \multirow{2}{*}{ Conclusion } \\
\hline$\underset{\text { Derum }}{\text { Dilution }}$ & Reaction & $\begin{array}{l}\text { Serum } \\
\text { Dilution }\end{array}$ & T. pallidum & T. Reiter & \\
\hline $1 / 40$ & - & $1 / 50$ & - & - & No reaction with Reiter treponeme \\
\hline $\begin{array}{l}1 / 40 \\
1 / 20 \\
1 / 360\end{array}$ & $\begin{array}{l}\overline{-} \\
\overline{-}\end{array}$ & $\begin{array}{l}1 / 50 \\
1 / 150 \\
1 / 450\end{array}$ & $\begin{array}{l}\overline{-} \\
\overline{-}\end{array}$ & $\begin{array}{l}\bar{z} \\
\overline{-}\end{array}$ & Anticomplementary serum activity probably the cause of false positive reaction \\
\hline $\begin{array}{l}1 / 40 \\
1 / 120 \\
1 / 360\end{array}$ & $\begin{array}{l}- \\
-\end{array}$ & $\begin{array}{l}1 / 50 \\
1 / 150 \\
1 / 450\end{array}$ & $\begin{array}{l}- \\
\overline{-}\end{array}$ & $\begin{array}{l}\overline{-} \\
\overline{-}\end{array}$ & $\begin{array}{l}\text { Reaction associated with an antipolysaccharide antibody elaborated in the } \\
\text { absence of treponematosis }\end{array}$ \\
\hline $\begin{array}{l}1 / 40 \\
1 / 120 \\
1 / 360\end{array}$ & $\begin{array}{l}+ \text { or }- \\
+ \text { or }-\end{array}$ & $\begin{array}{l}1 / 50 \\
1 / 150 \\
1 / 450\end{array}$ & $\begin{array}{l}+t \\
\pm \\
-\end{array}$ & \pm & Presence of group anti-protein antibody \\
\hline $\begin{array}{l}1 / 40 \\
1 / 120\end{array}$ & - & $\begin{array}{l}1 / 50 \\
1 / 150\end{array}$ & $=$ & - & Undetermined \\
\hline
\end{tabular}

† The serum of a former syphilitic in this category was negative. 
shown in Table V. All these extracts, at their optimum for the group protein-antiprotein system, fix complement because of the polysaccharide impurities they contain.

\section{TABLE V}

COMPLEMENT FIXATION. STUDY OF THE ACTIVITY OF DIFFERENT PROTEIN EXTRACTS WITH HUMAN ANTIPOLYSACCHARIDE ANTIBODY FIXING COMPLEMENT, COMPARED WITH ANTI-REITER SERUM AND SYPHILITIC SERUM

ONLY THE RESULTS GIVEN BY THE HIGHEST ACTIVE DILUTION OF EACH SERUM ARE SHOWN

\begin{tabular}{|c|c|c|c|c|}
\hline \multirow[b]{2}{*}{ Test } & \multirow[b]{2}{*}{ Dilution } & \multicolumn{3}{|c|}{ Serum (Dilution) } \\
\hline & & $\begin{array}{l}\text { Anti- } \\
\text { Reiter }\end{array}$ & $\begin{array}{c}\text { Syphilitic } \\
(1 / 8)\end{array}$ & $\begin{array}{c}\text { Human } \\
\text { containing } \\
\text { Anti-poly- } \\
\text { saccharide } \\
\text { fixing } \\
\text { Antibody } \\
(1 / 2)\end{array}$ \\
\hline $\begin{array}{l}\text { ATPS } \\
\text { (d'Alessandro } \\
\text { technique) }\end{array}$ & $\begin{array}{l}1 / 20 \\
1 / 60 \\
1 / 180 \\
1 / 540 \\
1 / 1,620 \\
\end{array}$ & $\begin{array}{l}- \\
++t+ \\
+t+t \\
t\end{array}$ & $\begin{array}{l}+++ \\
++++ \\
++ \\
-\end{array}$ & $\begin{array}{l}- \\
+ \\
++t+ \\
++t+ \\
++t\end{array}$ \\
\hline $\begin{array}{l}\text { ATPS } \\
\text { (de Bruijn } \\
\text { modification) }\end{array}$ & $\begin{array}{l}1 / 20 \\
1 / 60 \\
1 / 180 \\
1 / 540 \\
1 / 1,620\end{array}$ & $\begin{array}{l}+t \\
++t+ \\
++t+ \\
+\end{array}$ & $\begin{array}{l}+++ \\
++++ \\
+ \\
-\end{array}$ & $\begin{array}{l}- \\
+ \\
++t+ \\
++t+ \\
++\end{array}$ \\
\hline $\begin{array}{l}\text { Protein Extract } \\
\text { (Pillot and Faure } \\
\text { technique) }\end{array}$ & $\begin{array}{l}1 / 20 \\
1 / 60 \\
1 / 180 \\
1 / 540 \\
1 / 1,620\end{array}$ & $\begin{array}{l} \pm \\
+t \\
+t \\
t \\
-\end{array}$ & $\begin{array}{l}- \\
+ \\
++++ \\
+++t \\
-\end{array}$ & $\begin{array}{l}- \\
- \\
\frac{t}{t+t+} \\
t+t\end{array}$ \\
\hline
\end{tabular}

\section{Discussion}

For 17 per cent. of the sera showing an "isolated Reiter positive" reaction we did not find a positive complement-fixation reaction with the Reiter treponemal antigen. This variation falls within the limits for reproducibility of complement fixation and doubtless corresponds to sera at the reactivity limit.

For 23 per cent. of sera, we found anticomplementary activity. In general, anticomplementary sera are a frequent source of errors of interpretation. We have discussed this problem elsewhere (Pillot, 1963). Although the complement titre to be used, determined in the presence of cardiolipin antigen and Reiter treponemal antigen, is the same, the anticomplementary activity of these sera in the presence of Reiter treponemal antigen disappears only at a dilution double that necessary for total lysis in the presence of cardiolipin antigen. The reasons for this phenomenon are unknown.

We have shown the existence of positive complement-fixation reactions not associated with treponematosis, reactions linked to a polysaccharide- antipolysaccharide system. This system is very sensitive to the zone phenomenon and, for this reason, probably represents a single immunological system. The antigenic optimum of this system is very marked and is situated at a higher dilution than that corresponding to the antigenic optimum of the group protein-antiprotein system; also, by using several dilutions of the Reiter treponemal antigen, one can detect the existence of a protein-antiprotein system. The responsible polysaccharide is present in the fraction soluble in a 20 per cent. solution of trichloracetic acid, after ultrasonic treatment in alkaline medium and papainnization of the treponemes. If this extract is purified by acetone precipitation, only a small fraction of the former activity is found with the purified extract. This polysaccharide thus constitutes another polysaccharide antigen over and above those characterized by means of gel analysis with rabbit antiReiter serum (Pillot and Dupouey, 1964).

The polysaccharide responsible for the activity of human sera designated "isolated Reiter positive" is situated in the most external part of the treponemal sheath. We believe that the impossibility of revealing this polysaccharide anti-polysaccharide system in immunofluorescence is due to the extremely superficial location of this antigen which leads to its loss in the course of the different treatments. The fixing agent does not seem to be involved in this possible disappearance, for the use of different fixing agents (acetone, alcohol, heat, osmic acid, etc.) does not modify the results. We believe that the antigen is dispersed during washing, but the hypothesis of a rupture of the immunocomplex, because of the weak affinity of the antibody for the antigen, cannot be formally excluded.

The impossibility of revealing this polysaccharideantipolysaccharide system by precipitation in gel may be due to the weak concentrations of the reagents and of the antibody in particular, to poor diffusibility of the antigen, or perhaps to the non-precipitating character of the antibody. It is impossible to study the behaviour of this system by agglutination as the possible reaction is masked by the "natural" agglutinating antibodies present in all sera. Since all the available protein extracts react with the antipolysaccharide because of the impurities they contain, there is no hope of improving the specificity of the reaction for the sero-diagnosis of syphilis by use of this type of preparation.

We do not know the microbe or microbes responsible for producing this antibody. The subjects presenting this antibody have no history of fusospirochaetal sore throat or of relapsing fever. However, the serum of a subject convalescent from 
relapsing fever fixed complement with an ultrasonically-treated suspension of Borrelia, and we identified antigenic relationships between the Reiter treponeme and $B$. hispanica. We found that the level of this antibody remained constant in the three individuals examined several times; the interval between the samples varied from several months to 2 years.

Hunter, Deacon, and Meyer (1964) showed that, by saturating sera with an ultrasonate of the Reiter treponeme, it was possible to eliminate an antibody involved in the immunofluorescence reaction between sera of healthy individuals and $T$. pallidum at dilutions below $1 / 200$. We obtained the same result with our polysaccharide extract (np); this shows that the antibody responsible for the cross-reaction, in immunofluorescence, between normal sera and $T$. pallidum on the one hand, and between normal sera and the Reiter treponeme on the other, is an antipolysaccharide antibody. The antibody concerned is therefore neither the group anti-protein (which may be supposed to exist in all individuals but at a level so low that only immunofluorescence would be able to reveal it) nor the antipolysaccharide fixing complement, since the latter cannot be demonstrated by immunofluorescence.

The absence of a reaction attributable to the polysaccharide makes it possible to define more clearly the characteristics of a certain number of reactions in which the group protein-antiprotein is involved (12 per cent. of sera). More careful clinical research into the donors of such sera revealed a history of syphilis in one-third of them. Possibly the other positive reactions occurred in the absence of a history of treponematosis, but we were unable to draw a definite conclusion. Were this the case, the frequency of such reactions would, in any event, be extremely low. Among the sera classified as containing a group anti-protein was one serum of a former syphilitic which was negative to $T$. pallidum in immunofluorescence. If the dilution of the sera required to carry out the reaction is taken into account, immunofluorescence therefore reveals itself less sensitive than complement fixation in revealing the group anti-protein.

Lastly, in 19 per cent. of cases, in which the role of the polysaccharide-antipolysaccharide reaction was excluded, we were not able to determine the factor or factors responsible; the antibody level in such cases is always low. Certain reactions seemed to be linked to the group protein anti-protein reaction, complement fixation proving the most sensitive and immunofluorescence the least sensitive method. With the first preparation (1958-61) of Reiter treponemes, we had noted that some sera with "isolated Reiter positive" reactions fixed complement with certain constituents of the culture medium, with the yeast extract in particular. This constituent sometimes yielded submicroscopic precipitates that washing of the treponemes at $\mathrm{pH} 7 \cdot 2$ did not eliminate. This fact induced us to eliminate from the culture medium the disodium phosphate and the ammonium carbonate that accentuated this precipitation. Further, we increased the stability of the medium by using horse albumin instead of whole serum, thus assuring ourselves against false positive reactions due to previous sero-therapy.

In conclusion, the specificity of the complementfixation reaction with Reiter treponemal antigen is not absolute.

In an appreciable number of cases, difficult to indicate in exact figures because the number varies with the endemicity of syphilis in the human group considered (Table II), an "isolated Reiter positive" reaction has at least as great a chance of being a reaction specific for treponematosis as of being a false positive reaction.

We do not know exactly why the percentage of Reiter reactions originally regarded as non-specific for treponematosis is higher in Luxemburg than in Paris. Among the sera with "isolated Reiter positive" reactions, the frequency of the polysaccharideantipolysaccharide system is similar in the two cities. A variable degree of sensitivity of the complement fixation or local epidemiological conditions may cause this difference. It would be worth while to investigate various geographical areas to elucidate this problem.

At present one can be certain only of a positive complement-fixation reaction with the Reiter treponemal antigen in the absence of treponematosis and in connexion with a polysaccharide-antipolysaccharide system.

Despite the presence of antipolysaccharide antibody in 0.05 to 0.5 per cent. of individuals, it seems to us to be useful to carry out the complementfixation reaction with the Reiter antigen, since this simple technique permits the discovery of syphilis not revealed by cardiolipin antigen or even, in some cases, by the Nelson test.

\section{Summary}

Among individuals never having contracted treponematosis, 0.05 to 0.5 per cent. present an antipolysaccharide antibody in their serum that fixes complement with different preparations of the Reiter treponeme. This antibody can be revealed only by complement fixation.

All the preparations (ultrasonate, protein extract, 
etc.) contain the polysaccharide antigen at a reactive level.

This polysaccharide is situated in the treponemal sheath; it is different from the antigen of the Reiter treponeme responsible for the immunofluorescence of insufficiently-diluted normal sera.

Distinguishing between the polysaccharide-antipolysaccharide reaction and the group proteinanti-protein reaction is relatively easy; the second of these reactions remains a highly specific reaction for treponematosis.

\section{REFERENCES}

d'Alessandro, G., and Dardanoni, L. (1953). Amer. J. Syph., 37, 137.

de Bruijn, J. H. (1960). Antonie van Leeuwenhoek, 26, 317. (1961). Ibid., 27, 98.

Dupouey, P. (1962). Thèse Doctorat, Faculté de Médecine de Paris.

(1963). Ann. Inst. Pasteur, 105, 725; 949.

Hunter, E. F., Deacon, W. E., and Meyer, P. E. (1964). Publ. Hlth Rep. (Wash.), 79, 410.

Faure M., and Pillot, J. (1960). Ann. Inst. Pasteur, 99, 729.

Pillot, J. (1962). Ibid., 103, 231; 373.

- (1963). "Immunologie générale", In "Traité de biologie", by Olivier, p. 565. Maloine, Paris. (1965). Thèse de doctorat ès sciences. Paris.

- and Borel, L. J. (1961). C. R. Acad. Sci. (Paris), 252, 954.

and Daguet, G. L. (1964). Bull. Soc. franc Derm. Syph., in press.

and Dupouey, P. (1964). Ann. Inst. Pasteur, 106, $456 ; 617$.
- - - and Faure, M. (1960). Ibid., 98, 734.

_- _- , and Ryter, A. (1964). Ibid., 107, 484; 663.

- and Faure, M. (1959). Ibid., 96, 196.

Roemer, G. B., and Schlipköter, H. W. (1958). Z. Hyg., $145,422$.

Szernovicz, F., and d'Azambuja, S. (1960). Ann. Biol. clin., 18, 312 .

Vaisman, A.. and Hamelin, A. (1961). Bull. Wld Hlth Org., 24, 239.

Problème des réactions de fixation du complément positives en présence du tréponème de Reiter, en l'absence de syphilis.

Rôle d'un antigène polysaccharide

RÉSUMÉ

Parmi des individus qui n'ont jamais contracté de maladies à tréponèmes, 0,05 à $0,5 \%$ ont dans leur sérum un anticorps antipolysaccharide qui fixe le complément en présence de différentes préparations du tréponème de Reiter. Cet anticorps peut seulement être mis en évidence par fixation du complément.

Toutes les préparations (ultrasonat, extrait de protéine) contiennent l'antigène polysaccharide à un taux suffisamment élevé pour produire une réaction positive.

$\mathrm{Ce}$ polysaccharide est situé dans l'enveloppe du tréponème; il est différent de l'antigène du tréponème de Reiter qui est responsable de l'immunofluorescence des sérums normaux insuffisamment dilués.

La distinction entre les réactions polysaccharideantipolysaccharide et protéine-antiprotéine est relativement facile. La seconde de ces réactions reste une réaction hautement spécifique de la tréponématose. 